\title{
Thresholds, Triggers and Time - Erosion Risk on Evolving Reclaimed Landforms after Bauxite Mining in the Darling Range, Western Australia
}

\author{
F.C. Mengler Centre for Land Rehabilitation, The University of Western Australia, Australia \\ R.J. Gilkes Centre for Land Rehabilitation, The University of Western Australia, Australia
}

\section{BACKGROUND}

Some rehabilitated bauxite mines in southwestern Australia have accelerated gully erosion while the majority have little erosion. Anecdote suggests that gully erosion in rehabilitated forest is controlled by slope gradient but not all steep areas erode and conversely, some gentle slopes do. Mining companies aim to achieve erosion behaviour in rehabilitated areas similar to that of the surrounding forest - where large gullies are rare. We surveyed 26 eroding and erosion-prone rehabilitated hillslopes and developed descriptive models to predict the occurrence of gully erosion. A model of gully triggers implies that triggers and threshold effects are as influential as slope gradient and length in determining both the occurrence and severity of gully erosion. Many pre-existing triggers that predispose critical parts of a landscape to gully erosion activate only under threshold-excess conditions. Pinched concavities (thalwegs), shallow topsoil and gravel cover, erodible subsoil, high groundwater level, misplaced fauna habitats and irregular rehabilitation boundary edges are common erosion triggers. Slope angle and slope length, upslope catchment area, landscape position, soil storage and infiltration capacity, and rainfall (duration and intensity) are threshold variables. Many of these triggers and some thresholds can be identified and hence mitigated at the pre-mining stage. Topographic thresholds for gully erosion determined by the relationship between the critical slope $\left(S_{\text {cr }}\right)$ and contributing area $(A)$ at Boddington, Huntly and Willowdale bauxite mines are: $S_{\mathrm{cr}}=0.2 A^{-0.39}, S_{\mathrm{cr}}=0.05 A^{-1.66}$ and $S_{\mathrm{cr}}=0.02 A^{-1.59}$. Additionally, at the minimum catchment area for gully incision $(0.3 \mathrm{ha})$, critical premining slopes are $14^{\circ}$ for Boddington, $10^{\circ}$ for Huntly and $6^{\circ}$ for Willowdale. Landforms exceeding these conditions may need site-specific designs to mitigate gully erosion risk. The rate of cumulative erosion and gully development measured by erosion pins on selected hillslopes closely follows the trend of cumulative precipitation at least during the first three seasons of rehabilitation growth. After this time, most gullies reach stasis. Cumulative erosion of non-mined, natural slopes also closely follows cumulative precipitation but at much lower rates (about 30 times lower than gullied sites). A proposed model of site erosion potential versus contributing area suggests that sites with the biggest gullies are above a threshold separating low- and highstate erosion. The effect of fire and maturity on the stability of gullied, rehabilitated sites is unknown.

\section{INTRODUCTION}

\subsection{Steep Slopes, Erosion and Rehabilitated Landforms}

A 40-year history of rehabilitation for bauxite pits in southwestern Australia's jarrah forest has generally achieved satisfactory landforms. In some cases however, erosion rates have been unacceptable and large gullies have required intervention and additional remediation. A considerable amount of bauxite ore is held by deposits on steep forest areas ( 15 to $20 \%$ of future mining areas have a pre-mining slope $>11^{\circ}$ ) but the rehabilitation procedures to ensure stable landforms in these areas have not yet been identified. It is probably unfeasible to transport large amounts of fill to reduce the angle of slopes in steep mined areas. Additionally, no criteria exist defining the maximum slope that can be rehabilitated using conventional techniques - this is important not only for erosion but also occupational health as some activities on steep slopes are restricted due to machine limitations and employee safety concerns.

The rehabilitation and closure process after bauxite mining begins by rebuilding the soil profile and making landforms that will be stable and integrate with the topography of the surrounding forest. After mining, pit 
walls are "battered-down" and the terrain is landscaped to blend with the adjoining forest. Pit floors are then ripped to alleviate induced compaction and soil is returned (usually direct from a nearby cleared area) and spread as two separate layers. First a gravely layer known as overburden is spread $(\sim 30 \mathrm{~cm}$ to $\sim 70 \mathrm{~cm}$ thick). Following this a layer of sandy topsoil, rich in seed and organic matter is spread ( $\sim 5$ to $\sim 20 \mathrm{~cm}$ thick). Seeding, fertilizer and final tillage (scarification or ripping on contour) complete the rehabilitation process. Rehabilitated landforms are sometimes destabilised by gully erosion before vegetation is re-established. This erosion is more likely to occur on steeper slopes but shallow ones can also be affected. To ensure the stability of rehabilitated land and enable successful closure, we studied the causes of gully erosion on young (0-5 year old) rehabilitated bauxite mines.

\section{$1.2 \quad$ Erosion Thresholds}

\subsubsection{Landscape and soil (surface) thresholds}

Gullies are threshold-dependent and caused by factors such as land use and disturbance, susceptible soil, geomorphology, climate and others (Valentin et al., 2005). However, it is the relationship between the upslope drainage area $(A)$, measured in hectares (ha) and a critical slope gradient $\left(S_{\text {cr }}\right)$, measured in metres per metre $(\mathrm{m} / \mathrm{m})$ or degrees that chiefly determines the location of gully initiation on a hillslope (Vandaele et al., 1996). Critical area-slope relationships (e.g. Moore et al., 1988) predict that gullies form when:

$$
S_{\mathrm{cr}} \cdot A^{b}>t
$$

where $t$ is the threshold value and $b$ is an exponent that ranges from 0.4 and 0.7 for natural catchments (Hancock and Evans, 2006). The critical area-slope relationship for gully incision is also expressed as a power function between critical slope and area:

$$
S_{\mathrm{cr}}=a A^{-b}
$$

where $a$ is a coefficient and $b$ is an exponent. Other soil surface properties such as stone cover (Poesen et al., 1994), vegetation cover (e.g. Davenport et al., 1998), surface seals and crusts (e.g. Poesen, 1986 and Bodnár \& Hulshof, 2006), water repellence (MacDonald and Huffman, 2004) and the amount of mixing of subsoil with the surface layers during tillage can all affect the infiltration capacity of the surface and hence, thresholds for erosion initiation. Finally, flow erosivity thresholds (e.g. Loch and Silburn, 1996) also influence gully development although these will not be considered in this paper.

\subsubsection{Run-off, storm water storage, and infiltration thresholds}

Surface run-off occurs when the volume and rate of delivered water exceed the storage capacity of the soil profile. The storage of storm water within the soil profile depends on antecedent wetness, soil depth, and soil porosity. Preceding rainfall events determine antecedent wetness and affect the capacity of the soil profile to store storm water. When the soil is dry, a large proportion of storm water is spent on wetting the profile resulting in little run-off. A soil profile close to saturation however, may require only small amounts of storm water to cross a threshold and produce surface run-off. Subsurface stormwater flow can occur when subsurface bedrock depressions on a hillslope fill and water spills over microtopographic relief in the bedrock surface. Saturated areas within the subsurface are then connected. Connectivity can increase the total subsurface stormflow rates by 75 times or more than when connectivity is lacking (Tromp-van Meerveld and McDonnell, 2006). Similarly, when storm water supply exceeds the above-surface storage capacity (tilled furrows), spills occur above ground, with the rapid release of stored water often initiating erosion. As well as storage capacity, a soil's infiltration capacity changes by threshold during storms. The infiltration capacity for most soils rapidly declines during the early stages of a storm; after a couple of hours, it tends to be constant for the remainder of the storm (Horton, 1933). Though infiltration capacity is high in coarse textured soils such as Darling Range topsoils and overburdens, this rapidly decreases vertically at the boundary with the underlying pit floor regolith composed of finer-textured material.

\subsection{Erosion Triggers}

Gullies form from a complex interplay of both surface and subsurface triggers. Gully triggers can include clear-cutting of indigenous forest (e.g. Parkner et al., 2006), and surface and topographic nonuniformities 
(Moore et al., 1988) such as knickpoints, bare patches, boulders, woody waste piles and tillage irregularities. Though they usually act as protective armour, certain amounts and arrangements of surface rock fragments can also trigger gullies (e.g. Poesen et al., 1994). Other triggers can include linear landscape elements such as parcel borders, field roads and plough furrows (Vandaele et al., 1996). However, the most important trigger is periods of high frequency extreme rainfall events (Valentin et al., 2005).

\subsection{Erosion and Soil/Landscape Evolution}

A typical gully grows $>90 \%$ of its eventual length during its first $5 \%$ of its lifetime. After this, growth is more complex, with phases of activity and relative dormancy (Wainwright et al., 2006). On land that is cultivated annually, gullies can ephemerally reappear with each annual fallow (Vandaele et al., 1996), but in regenerating ecosystems with scrub vegetation, gully activity decreases with time (e.g. Parkner et al., 2006).

\section{METHODS}

\subsection{Site Description}

Alcoa World Alumina Australia (Alcoa) operates the Huntly (32 $\left.37^{\prime} \mathrm{S}, 116^{\circ} 03^{\prime} \mathrm{E}\right)$ and Willowdale (32 $50^{\circ} \mathrm{S}$, $116^{\circ} 03^{\prime} \mathrm{E}$ ) bauxite mines and Worsley Alumina Ltd. (Worsley) operates the Boddington bauxite mine $\left(32^{\circ} 57^{\prime} \mathrm{S}, 116^{\circ} 27^{\prime} \mathrm{E}\right)$ in the Darling Range in the southwest of Western Australia. Annual rainfall (ten-year average) at each mine is $1227 \mathrm{~mm}, 1207 \mathrm{~mm}$ and $723 \mathrm{~mm}$ for Huntly, Willowdale and Boddington respectively, with most of this falling during the months surrounding the winter season (May to September).

\subsection{Geomorphic and Soil Survey}

To determine erosion triggers, we surveyed 26 sloping sites including 22 sites with active rills or gullies and four steep-sloping sites where erosion was expected but was absent. Sites represent the range of different soil profiles and steep topography that is considered more prone to erosion than rehabilitated sites of low relief. A separate set of 5 non-mined, steeply sloping sites was also included as a control. We surveyed, categorised and measured erosion-influencing variables and erosion expression at each site organized into the following groups:

- Pit character.

- Hillslope form.

- Rehabilitation management.

- Soil surface and cover.

- Underlying regolith.

- Gully character.

\subsection{Erosion Rate Prediction}

The empirical Revised Universal Soil Loss Equation (Renard et al., 1996) or RUSLE model was used to determine an annual rate of potential soil loss for each site using data from Mengler and Gilkes (in prep.). RUSLE uses the following regression relation to estimate soil loss:

$$
\mathrm{A}=\mathrm{R} \cdot \mathrm{K} \cdot \mathrm{LS} \cdot \mathrm{CP}
$$

Where: $\mathrm{A}=$ estimated rate of soil loss $(\mathrm{t} / \mathrm{ha} / \mathrm{yr}) ; \mathrm{R}=$ rainfall erosivity index $[(\mathrm{MJ} \cdot \mathrm{mm} /(\mathrm{ha} \cdot \mathrm{h} \cdot \mathrm{yr})] ; \mathrm{K}=$ soil

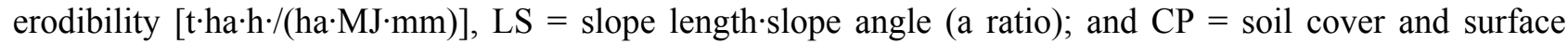
treatment (a ratio). Rainfall erosivity values where taken from McFarlane et al. (1986). Rainfall (R) was kept constant $\left(\mathrm{EI}_{30}=200\right)$ for Huntly and Willowdale and reduced by $40 \%\left(\mathrm{EI}_{30}=120\right)$ for Boddington. The CP factor was a constant 0.5 and 0.3 for eroding and non-eroding sites respectively. 


\subsection{Hillslope Angle - Its Importance and Measurement}

There are many ways to measure slope but there is currently no agreement on how to best calculate slope for rehabilitation planning. Should we do the following:

- Measure pre-mining or post-mining slope.

- Measure slope in the field or interpolate from mapped contours.

- Generate slope as digital pixels within a geographic information system (GIS)?

As there is no accepted measure of slope we therefore lack evidence on what slope presents a significant erosion risk. During planning, it is not always possible to know the post-mining slope, so in this paper we use pre-mining slope to develop critical slope angles for rehabilitation planning.

\subsection{Area-Slope Relationship and Derivation of Topographic Thresholds}

Hydrologically correct digital elevation models (DEMs) at a resolution of $20 \mathrm{~m}$ by $20 \mathrm{~m}$ representing the premining terrain at each bauxite mine were generated with the Topogrid command using ESRI's ARCINFO 7.1. Area-slope relationships for all surveyed gully locations were subsequently derived from the DEMs using the Slope and Flow Accumulation subroutines. Digital elevation data (5 m contours) representing the pre-mining land condition for Huntly, Willowdale and Boddington were supplied by the Department of Land Information, Western Australia. Topographic thresholds of critical slope-area $\left(S_{\mathrm{cr}}-\mathrm{A}\right)$ relationships for gully incision at each mine were determined by fitting lines through the lower-most points on $S_{\text {cr }}$-A plots.

\subsection{Erosion Pin Plots}

An erosion pin is a metal rod (length $600 \mathrm{~mm}$, diameter $<10 \mathrm{~mm}$ ) hammered into the soil to a depth where it is beyond disturbance by incidental tramping (Haigh, 1977). Erosion pins measure changes in ground surface elevation with an accuracy of $\pm 1 \mathrm{~mm}$ and indicate true soil loss when records are compared over a number of years. Pins were hammered into the surface to an initial exposure of about $250 \mathrm{~mm}$, taking care not to disturb the surrounding soil. Bright flagging on the top of each pin made them more visible as vegetation recovered. A protective tin placed around an extra pin per site accounted for settling and provided a correction factor for measurements. The difference between the length exposed on the unprotected pin and its protected twin was the depth of soil lost due to erosion (thereby accounting for any settling). Pins were set $2 \mathrm{~m}$ apart in lines of up to 10 pins at 5 metre-intervals down the hillslope on gullied plots for a range of slopes. Measurements of erosional change were compared to cumulative precipitation at three-monthly intervals.

\section{$3 \quad$ RESULTS}

\subsection{Development of Gullies}

\subsubsection{Triggers}

A combination of concentrated flow and trigger points caused gully headcut incision. Ponding, crusted soil and silt-filled furrows were present upslope at many gully headcuts - providing a setting for "fill and spill" overland flow (e.g. Tromp-van Meerveld and McDonnell, 2006) to occur. Small pipe-like openings 2-15 cm wide on the face of tilled furrows upslope of a gully at Taipan 10 indicate that piping and subsurface flow may have contributed to some gullies at this site. The most common setting for gully erosion was at points in the landscape where water run-off from upslope forest areas was concentrated onto the steep shoulders of rehabilitated hillslopes. A poor standard of rehabilitation tillage (off contour, incomplete, or not seamlessly tied into adjoining areas) led to run-off concentration. Gullies incised wherever this concentrated run-off met a trigger such as concavities, thalwegs, knickpoints, boulders, poorly-installed fauna habitats or the remnants of waste rock dumps. Insufficient depths of returned topsoil and overburden (less than $20 \mathrm{~cm}$ combined) also triggered gully erosion. Steep gradients or long slope lengths made gullies more severe but did not trigger gullies. 


\subsubsection{Rates}

Our knowledge of erosion in rehabilitated forest is influenced by the contrasting erosion rates between a number of sites examined over the past three years. These sites at Huntly, Willowdale and Boddington bauxite mines have similar soil properties, climate and vegetation cover. One site has experienced very high rates of gully erosion, while at other sites erosion rates have been moderate to low. The rapidly eroding site (Taipan 10 pit, Willowdale) entered its high erosion rate during a rain period over several days during the winter of 2003. Multiple gullies at the site were deeper and wider than $2 \mathrm{~m}$, exposing erodible mine floor regolith in gully floors and sides. The cumulative trend of mean erosion for a gullied plot at Taipan 10 closely followed the trend of cumulative precipitation (Figure 1). A nearby non-mined slope of similar gradient to Taipan 10 had cumulative mean erosion trend that also followed the trend of cumulative precipitation but was around 30 times lower than the rehabilitated site (Figure 2). A gullied site at Huntly mine (Chipala 79) also initiated during the winter of 2003 but after an initially rapid rate, the evolution of the Chipala 79 gully was at a much slower rate than the Taipan 10 gully. Furthermore, the gully at Chipala 79 has reached stasis - the cumulative erosion line crossed the precipitation line at the end of winter 2005 (Figure 3). Gullies at other plots reached maximum size two or three years after rehabilitation.

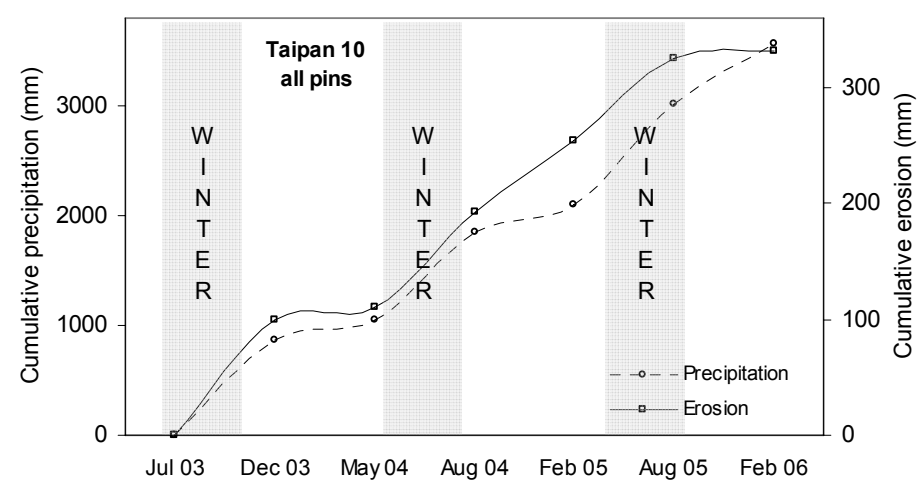

Figure 1 Cumulative mean erosion $(n=84)$ for a gullied erosion pin plot at Taipan 10, Willowdale (average angle of plot slope $=17^{\circ}$ )

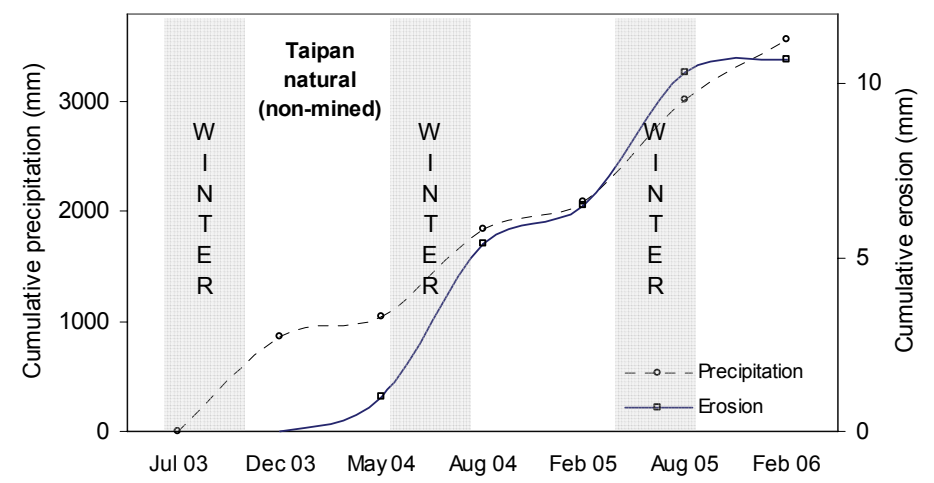

Figure 2 Cumulative mean erosion $(n=20)$ for an intact (non-mined) erosion pin plot at Taipan 10, Willowdale (average angle of plot slope $=16^{\circ}$ ) 


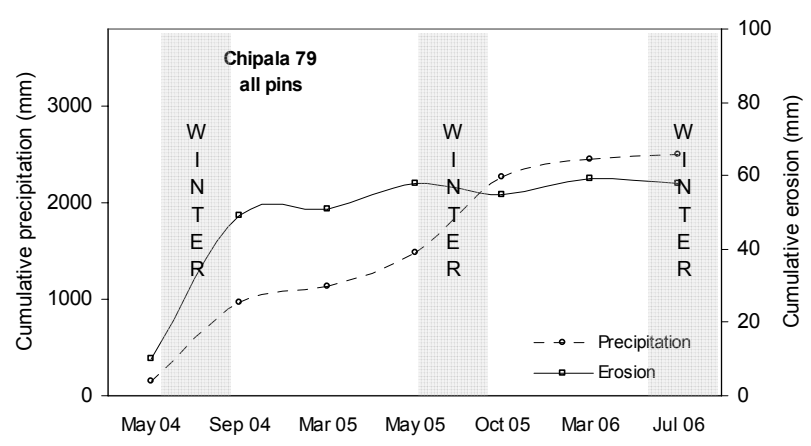

Figure 3 Cumulative mean erosion $(n=50)$ for an intact (non-mined) erosion pin plot at Chipala $7 / 9$, Huntly (average angle of plot slope $=14^{\circ}$ )

\subsection{Topographic Thresholds}

The relationship between catchment area and slope for gullies on rehabilitated hillslopes and the topographic threshold for gully development on each mine is given in Figure 4. As explained above, almost all gullies attained their maximum extent and reached stasis after about three years since rehabilitation, when upslope catchments and immediate surroundings started to be fully covered by both understory and young overstory plant species. Each of the three bauxite mines studied had a different topographic threshold - Boddington had the greatest and Willowdale the lowest. Values for the area-slope relationship for gullied- and nongullied slopes at all mines suggest that greater than 0.3 ha of catchment area needs to concentrate flow at a point for gullies to develop. Below this threshold, no gullies should occur. Beyond 0.6 ha catchment area, and beyond $10^{\circ}$ slope, large gullies $\left(>100 \mathrm{~m}^{3}\right.$ of volume) can occur, but not in all cases. At slopes less than $10^{\circ}$, even at relatively large areas of catchment draining through a point $(>1$ ha), gullies are usually small (less than $20 \mathrm{~m}^{3}$ of volume). At the minimum catchment area of 0.3 ha for gully incision, critical pre-mining slopes for Boddington, Huntly and Willowdale are $14^{\circ}, 10^{\circ}$ and $6^{\circ}$ respectively. Additionally, the topographic thresholds for Boddington, Huntly and Willowdale are:

$S_{\mathrm{cr}}=0.2 A^{-0.39}, S_{\mathrm{cr}}=0.05 A^{-1.66}$ and $S_{\mathrm{cr}}=0.02 A^{-1.59}$ respectively. Differences between the thresholds of the three mines reflect different rainfall patterns and in the case of Willowdale, thinner than average returned soil profiles on the gullied slopes that were investigated.

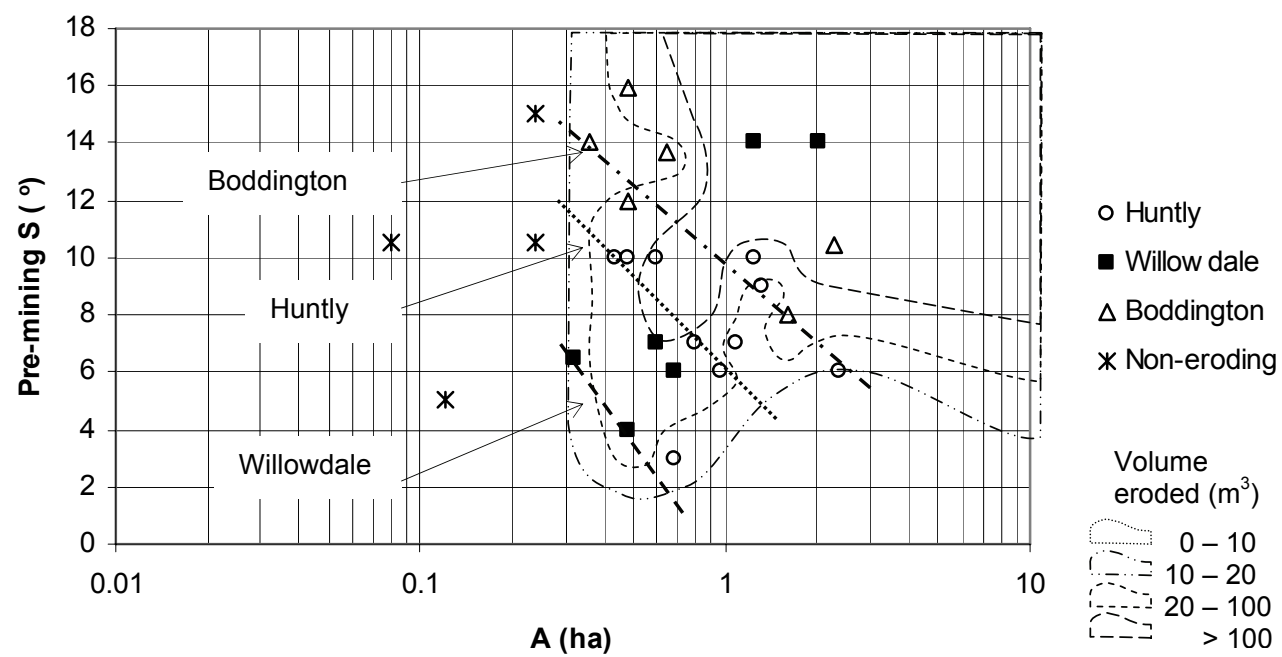

Figure 4 Critical pre-mining slope (S) angle versus upslope drainage area (A) and volume of material eroded for rehabilitated bauxite pits with gullies. Straight lines fitted through the lower-most points of the slope angle - upslope drainage area are thresholds below which little or no incision occurs 


\section{DISCUSSION}

The use of models such as the RUSLE (Renard et al., 1996) allow prediction of erosion under a variety of conditions, including high and low rates but these models do not account for gullies nor do they give any clear conceptual framework explaining the occurrence of erosion thresholds. We developed three types of model to describe the: 1.) triggers; 2.) thresholds; and 3.) evolution of gully erosion on hillslopes rehabilitated after bauxite mining. The models are consistent with field observation across all sites within the Darling Range.

\subsection{Gully Triggers}

The model in Figure 5 shows two types of gully triggered by effects such as ponding, overland flow, installed fauna habitat, poor ripping leading to lateral flow concentration, piping and seepage. Gullies of type A are caused by the concentration of fast-moving, surface water in excess of infiltration capacity during "fill and spill" episodes involving the overflowing of ponds within contour furrows upslope. These gullies form when rapid flows cut down into weak topsoil and overburden materials. Once formed, they act as conduits for more upslope and lateral surface flow. Gullies of type B are caused by substrates that are saturated either by inherently slow-draining subsoil or by geological impediments to groundwater flow. Some Type B gullies develop from small pipe-like seepage outlets in upslope contour mounds. Type B gullies form more slowly than Type A gullies, mainly by seepage, slumping, and/or mass wasting. Once Type B gullies form, they evolve similarly to Type A gullies, but can act as conduits for both surface and subsurface flow. The steepness of the gradient and the length of slopes do not trigger erosion alone but both make gully erosion more severe when associated with triggers.

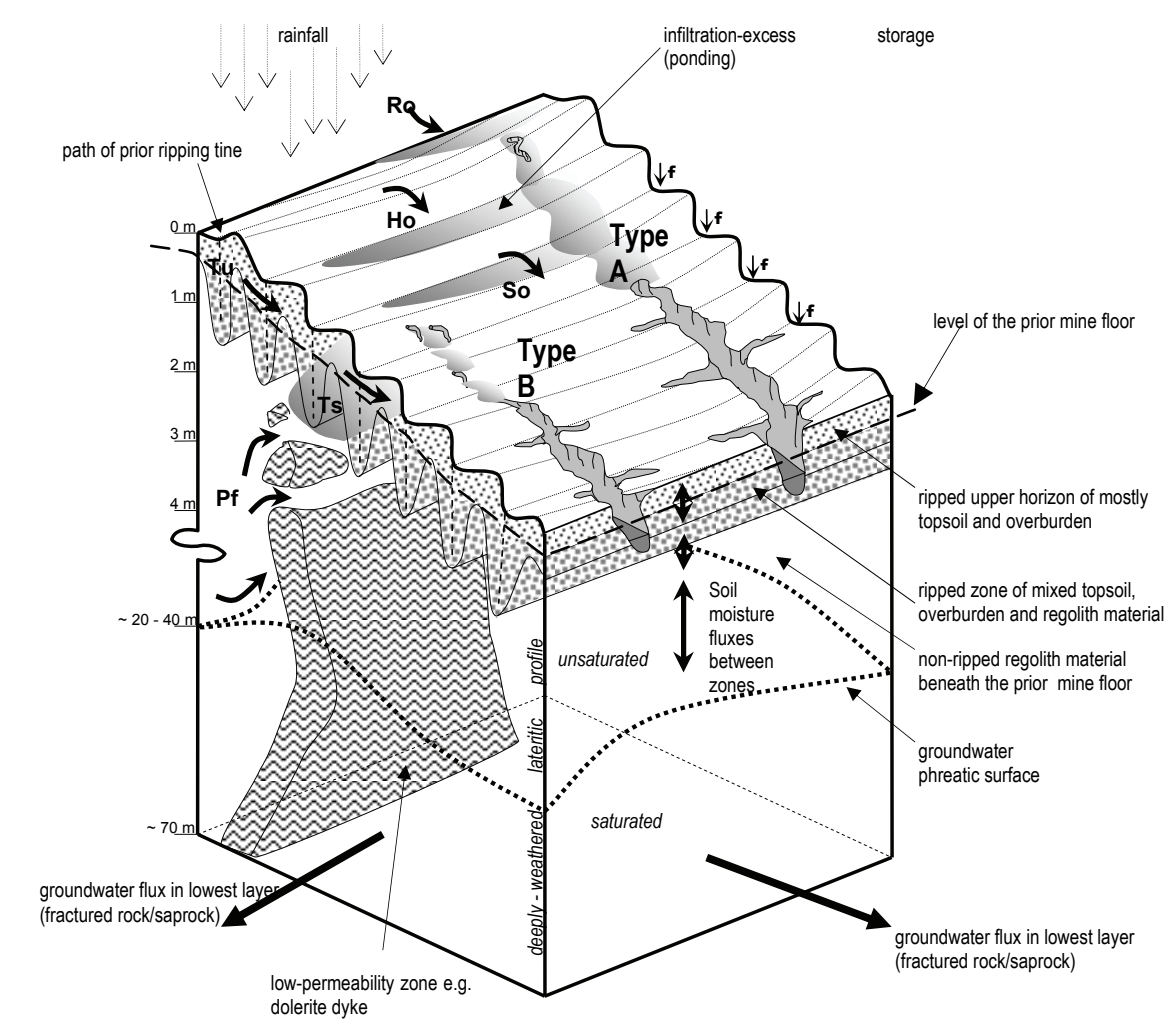

Figure 5 Conceptual gully trigger model for a typical rehabilitated hillslope. So, saturated overland flow; Ho, Hortonian overland flow; f, infiltration; Ts, saturated through flow; Tu, unsaturated through flow; Pf, perched aquifer flow; Ro, run-on flow from upslope forest (Processes from Gerrard, 1981) 


\subsection{Empirical Thresholds for Gully Size}

Contrasting erosion rates at different sites and the extreme rates at the Taipan 10 site suggest that threshold effects cause and control gully erosion on post-bauxite mining soils and landforms. We plotted RUSLEpredicted erosion rates (providing a measure of site erosion potential) against the upslope catchment area draining through each gully headcut. Sites with the largest gullies (measured as total volume of soil lost from all gullies at the site) also have the greatest potential erosion rates and greatest upslope catchment areas (Figure 6). Sites with smaller gullies have lower potential erosion rates and catchment areas. The magnitude of difference between the numerous small peaks and troughs (below the low-state erosion line) and the large peaks (above the high-state erosion line) in the model indicate that a threshold from low- to high-state erosion has been crossed at sites with the largest gullies (Figure 6).

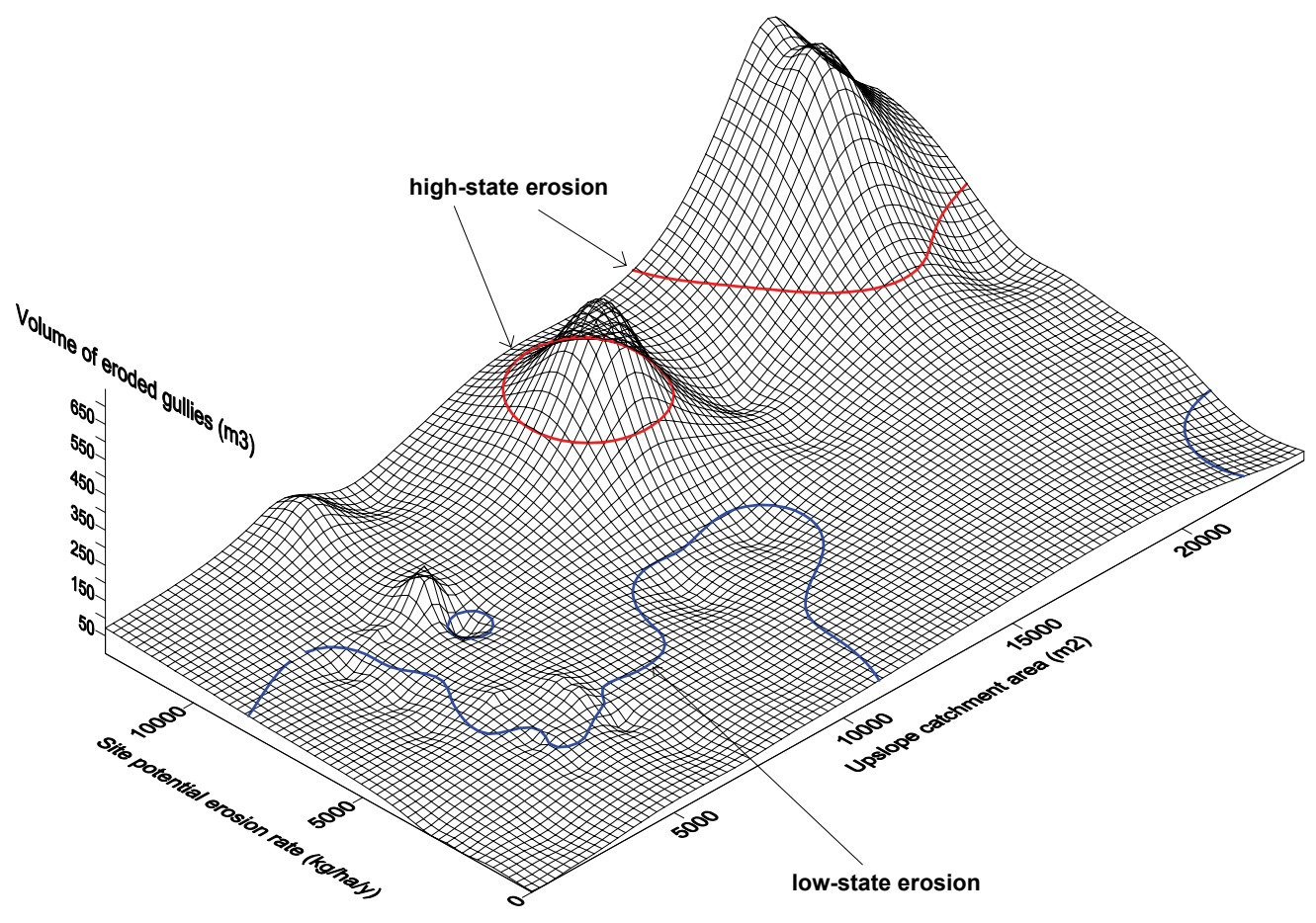

Figure 6 Integral gully threshold model - site potential, drainage area and gully volume

\subsection{Evolution of the Topographic Threshold}

We developed a schematic model of the evolving topographic threshold for gully erosion (Figure 7) adapting our results to an existing temporal model (Parkner et al., 2006). A high initial threshold for intact jarrah forest declines drastically with the removal of vegetation and mining of the soil profile. Resistance to concentrated flow reduces and sensitivity to relatively small storms and changes to the intensity of rainfall and run-off from forest areas is increased. With the onset of vegetation regrowth, the threshold improves until it passes a critical value unique to each site, usually after two or three years of rehabilitation. However, the long-term evolution of most gullies is complex, including phases of activity and relative dormancy (Wainwright et al., 2006) so we are uncertain how fire and forest maturation will affect gullied sites. 


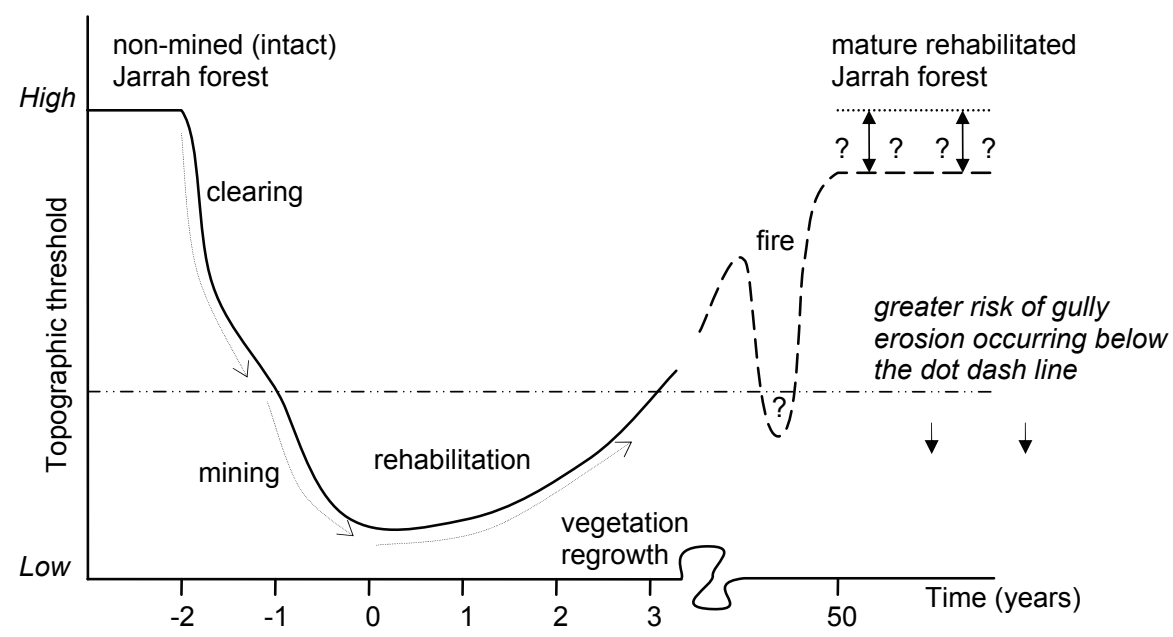

Figure 7 Schematic model of the evolving topographic threshold for gully erosion

\subsection{Management Responses}

Though mining companies would prefer a standard rehabilitation prescription for all areas, problems can arise when management practices developed for a particular site are applied at other sites with very different conditions. Fundamental to reducing gully formation on steeper hillslopes is strict adherence to tillage on the contour. This tillage should aim to produce low furrow profiles (i.e. shallow, multiple-tine ripping implements are preferable to deep, single tines). Blasting to fracture excessive caprock upslope of rehabilitated areas will reduce flow from forest into rehabilitation. Drillers' logs should be queried for areas of perched groundwater and preparations made in advance to deal with seepage and excessive in-pit water production. Installed fauna habitats are piles of rock and logs emplaced on rehabilitated pits to encourage the return of animals. Fauna habitats should be placed well downslope (at least $50 \mathrm{~m}$ ) of hillslope shoulders and large boulders ( $>60 \mathrm{~cm}$ diameter) should not remain on steep slopes. An adequate soil depth (at least $40 \mathrm{~cm}$ combined topsoil and overburden) must be returned to steep hillslopes at all mines - even at Boddington where annual rainfall is lower. Management practices usually focus on ripping but in some cases at least, ripping can overwork the soil, lowering its strength and making it more vulnerable to erosion. On vulnerable (very steep) hillslopes, it might be practical to trade-off some improved structure for plant roots by not preripping. The resulting soil would be less friable but have greater strength and hence, stability. Having said this, pre-ripping also improves water infiltration so perhaps more research on this aspect is needed.

\section{CONCLUSIONS}

A combination of the following major triggers can cause gully erosion:

- Excess off-site water supply into the eroding area.

- Poor surface completion resulting in concentrated flow and/or poor infiltration.

- Insufficient depth of returned topsoil and overburden (less than $\sim 20 \mathrm{~cm}$ combined).

Minor gully erosion triggers are:

- Remnant forest islands within pits.

- Fauna habitats displacing contour lines.

- Irregular upslope pit boundaries.

- Non-ripped caprock at pit edges.

- Shallow groundwater. 
Steeper slopes and longer slope lengths intensified the severity of erosion where they combined with one or more major or additional minor erosion triggers. Most gully erosion initiated at the upper parts of rehabilitated hillslopes, either at the base of a shoulder or on backslopes. Area-slope relationships show that no gullies or small ones (less than $20 \mathrm{~m}^{3}$ of volume) occur at slopes from 0 to $14^{\circ}$ where catchment area is less than 0.4 ha. Beyond 0.6 ha catchment area, and beyond $10^{\circ}$ slope, large gullies $\left(>100 \mathrm{~m}^{3}\right.$ of volume) can occur but not in all cases. At slopes less than $10^{\circ}$, even at relatively large areas of catchment draining through a point ( $>1 \mathrm{ha}$ ) gullies are usually small (less than $20 \mathrm{~m}^{3}$ of volume). Soil erodibility (RUSLE Kfactor) values of rehabilitated surface soils are low to very low. However, more-erodible media occurred where: mine floor material mixed with topsoil/overburden; and/or the topsoil/overburden layer was thin or its coverage was patchy, resulting in slaking subsoil, hardsetting soil and surface crusts. Gully development was greatly intensified when erodible surface media were combined with steeper $\left(>8^{\circ}\right)$ or longer $(>50 \mathrm{~m})$ slopes or with any major erosion trigger being present. Erosion rates for gullied sites should decline two or three years after rehabilitation. Additional remediation to repair small gullies may not be necessary if they have reached stasis. At sites that have crossed a threshold from low to high-state erosion, rates may not reduce much in the first years of rehabilitation. Active gullies at sites with high-state erosion will probably require additional rehabilitation, increasing the cost of mine closure. The effect of bushfire on gully re-initiation is unknown.

\section{ACKNOWLEDGEMENTS}

Funding was provided by MERIWA, Alcoa World Alumina Australia and Worsley Alumina Ltd. Carl Grant, Ken McIntosh, Glen Ainsworth, Steve Vlahos, Rochelle Jones and Haakon Nielssen all provided advice, assistance and access to study sites. Greg Hancock advised on the use of topographic thresholds.

\section{REFERENCES}

Bodnár, F. and Hulshof, J. (2006) Soil crusts and deposits as sheet erosion indicators in southern Mali. Soil Use and Management 22, pp. 102-109. DOI: 10.1111/j.1475-2743.2006.00010.x.

Davenport, D.W., Breshears, D.D., Wilcox, B.P. and Allen, C.D. (1998) Viewpoint: sustainability of pinon-juniper ecosystems - a unifying perspective of soil erosion thresholds. Journal of Range Management 51, pp. $231-240$.

Gerrard, A.J. (1981) Soils and Landforms. George Allen and Unwin Ltd. London, 219 p.

Haigh, M.J. (1977) Use of erosion pins in the study of slope evolution. British Geomorphological Research Group Technical Bulletin 18, pp. 31-49.

Hancock, G.R and Evans, K.G. (2006) Channel head location and characteristics using digital elevation models. Earth Surface Processes and Landforms (in press) DOI: 10.1002/esp.1285.

Horton, R.E. (1933) The role of infiltration in the hydrological cycle. Trans. American Geophys. Union 14, pp. 446460.

Loch, R.J. and Silburn, D.M. (1996) Constraints to sustainability — soil erosion. In L. Clarke and P.B. Wylie (eds) Sustainable Crop Production in the Sub-tropics: an Australian Perspective. QDPI.

MacDonald, L.H. and Huffman, E. L. (2004) Post-fire soil water repellency: persistence and soil moisture thresholds. Soil Science Society of America Journal 68, pp. 1729-1734.

McFarlane, D.J., Davies, R.J. and Westcott, T. (1986) Rainfall erosivity in Western Australia. In Proceedings of the Hydrology and Water Resources Symposium, Griffith University, Brisbane. Institution of Engineers, Australia, Barton, ACT, pp. 350-354.

Mengler, F.C. and Gilkes, R.J. (2007) Landscape, soil surface and management practices control gully erosion on steep rehabilitated landforms after bauxite mining in the Darling Ranges, Western Australia. Catena (in prep.).

Moore, I.D., Burch, G.J. and Mackenzie, D.H. (1988) Topographic effects on the distribution of surface soil water and the location of ephemeral gullies. Transactions of the American Society of Agricultural Engineers 34, pp. 10981107.

Parkner, T., Page, M.J., Marutani, T. and Trustrum, N.A. (2006) Development and controlling factors of gullies and gully complexes, East Coast, New Zealand. Earth Surface Processes and Landforms 31, pp. 187-219. 
Poesen, J. (1986) Surface sealing as influenced by slope angle and position of simulated stones in the top layer of loose sediments. Earth Surface Processes and Landforms 11, pp. 1-10.

Poesen, J.W., Torri, D. and Bunte, K. (1994) Effects of rock fragments on soil erosion by water at different spatial scales: a review. Catena 23, pp. 141-166.

Renard, K.G., Lane, L.J., Foster, G.R. and Laflen, J.M. (1996) Soil Loss Estimation. In M. Agassi (ed) Soil Erosion, Conservation and Rehabilitation. Marcel Dekker, New York, pp. 169-202.

Tromp-van Meerveld, H.J. and McDonnell, J.J. (2006) Threshold relations in subsurface stormflow 2. The fill and spill hypothesis. Water Resources Research 42, 11 p. W02411, doi:10.1029/2004WR003800.

Valentin, C., Poesen, J. and Yong, L. (2005) Gully erosion: Impacts, factors and control. Catena 63, pp. 132-153.

Vandaele, K., Poesen, J., Govers, G. and van Wesemael, B. (1996) Geomorphic threshold conditions for ephemeral gully incision. Geomorphology 16, pp. 161-173.

Wainwright, J., Mathys, N. and Esteves, M. (2006) Gully erosion in mountain areas: processes, measurement, modelling and regionalization. Earth Surface Processes and Landforms 31, pp. 133-134. DOI: 10.1002/esp.1318. 